\title{
Analysis of Secondary Refining Slag Parameters with Focus on Inclusion Cleanliness
}

\author{
Julio Aníbal Morales Pereira ${ }^{a} \oplus^{-}$, Vinicius Cardoso da Rocha ${ }^{a}$, Ayumi Yoshioka ${ }^{b}$,
}

\author{
Wagner Viana Bielefeldt", Antônio Cezar Faria Vilela ${ }^{a}$
}

\author{
${ }^{a}$ Departamento de Metalurgia, Universidade Federal do Rio Grande do Sul, Porto Alegre, RS, Brasil \\ ${ }^{b}$ Departamento de Pesquisa e Desenvolvimento, Gerdau Charqueadas, Charqueadas, RS, Brasil
}

Received: April 23, 2018; Accepted: June 26, 2018

\begin{abstract}
Secondary refining slag samples with different chemical compositions (45-54 \% $\mathrm{CaO}, 7-13 \%$ $\mathrm{Al}_{2} \mathrm{O}_{3}, 20-29 \% \mathrm{SiO}_{2}, 9-16 \% \mathrm{MgO}, 0-5 \% \mathrm{CaF}_{2}$ ) were investigated to verify the influence of their effective viscosity on inclusion cleanliness of DIN $38 \mathrm{MnS} 6$ in a steelmaking plant. The steel samples were collected during the production process for analysis of inclusions. Using the commercial software FactSage 6.4, thermodynamic calculations were performed to determine the effective viscosity, solid fraction, liquid fraction and $\mathrm{MgO}$ saturation point of these slags at $1560^{\circ} \mathrm{C}$. The results showed that all the slags were saturated in $\mathrm{MgO}$, revealing a better protection of the ladle refractory. The addition of 2 to $5 \%$ of $\mathrm{CaF}_{2}$ reduced the effective viscosity values for the analyzed slags from $0.45 \mathrm{~Pa} \cdot \mathrm{s}$ to 0.10 $\mathrm{Pa} \cdot \mathrm{s}$, in comparison to the slags without the addition of $\mathrm{CaF}_{2}$, with an effective viscosity of $0.40 \mathrm{~Pa} \cdot \mathrm{s}$, $0.27 \mathrm{~Pa} \cdot \mathrm{s}$ and $0.22 \mathrm{~Pa} \cdot \mathrm{s}$, decreasing the level of non-metallic inclusions for some of the analysed heats. However, it was detected during the manufacturing process that high slag fluidity and re-oxidation events continue to be a challenge associated with reducing the level of non-metallic inclusions.
\end{abstract}

Keywords: refining slags, viscosity, inclusions, clean steels, secondary metallurgy.

\section{Introduction}

The DIN 38MnS6 steel, due to its application in the mechanical industry through automotive components, requires that steel-melting shops improve the conditions for clean steel production (reduction of inclusions) during the manufacturing process. Through these improved conditions, the mechanical properties and, especially, fatigue of this type of steel are guaranteed, increasing the quality of steel produced by the industry. Conditions which can be improved in this context, are those of the secondary steel refining processes, where the chemical composition and effective viscosity of the slag used has a significant effect on the kinetics of the refining reactions. Furthermore, these conditions add to the removal and dissolution of inclusions throughout the steel-slag interface, as well as facilitate the removal of gases from liquid steel ${ }^{1-9}$. In order to achieve these conditions, metallurgists often prefer completely liquid slags in the ladle treatment. Slags with high solid phase fractions can increase their viscosity and delay refining operations. Since changing the slag composition has a strong effect on its viscosity, it is common to use slags containing fluorite $\left(\mathrm{CaF}_{2}\right)$, as this reduces their viscosity and melting point. The addition of alumina $\left(\mathrm{Al}_{2} \mathrm{O}_{3}\right)$ should amplify this effect and produce slags with higher liquid fraction ${ }^{3,10-15}$. The impact of top slag viscosity has been investigated by many researchers. Sui et al. ${ }^{3}$ indicate that additions of $\mathrm{CaF}_{2}$ and $\mathrm{Al}_{2} \mathrm{O}_{3}$ in the slag used in the refining unit effectively decrease the slag viscosity. $\mathrm{Wu}^{12}$, concludes that the effect of $\mathrm{CaF}_{2}$ on viscosity

*e-mail: juliolasid@yahoo.com.br strongly depends on the composition of the slag, and this effect is greater on slags with higher $\mathrm{SiO}_{2}$ content. For high basicity slags, $\mathrm{CaF}_{2}$ represses the precipitation of solid phases at low temperatures, leading to low viscosities compared to slags without the presence of $\mathrm{CaF}_{2}$. Shahbazian et al. ${ }^{16}$, reports that in liquid slags containing $\mathrm{Al}_{2} \mathrm{O}_{3}$, aluminate complexes $\mathrm{Al}_{3} \mathrm{O}_{7}^{5-}, \mathrm{AlO}_{2}, \mathrm{AlO}_{3}{ }^{3-}$ can be formed. As the amount of $\mathrm{CaF}_{2}$ increases, aluminate anions can be depolymerized. The disintegration of the aluminate complexes into smaller units results in a decrease in viscosity. According to the studies of Asth ${ }^{14}$ and Bartosiaki et al. ${ }^{17,18}$, an excess of refractory oxides $(\mathrm{CaO}$ and $\mathrm{MgO})$ can increase the viscosity of slags due to the presence of solids $(\mathrm{CaO}$ precipitation or $\mathrm{CaO}$ rich phases, spinels $\left(\mathrm{MgO} \cdot \mathrm{Al}_{2} \mathrm{O}_{3}\right)$ and $\left.\mathrm{MgO}\right)$ which are detrimental to the process of nonmetallic inclusion removal. According to Valdez et al. ${ }^{7}$, increasing the viscosity of the slag (by the effect of solid phase precipitation) causes a much longer time for the inclusions to be completely removed from liquid steel, and in the case of a low viscosity slag, the particle can be more easily removed through it. Studies of the influence of basicity on the viscosity of the refining slag have concluded that with higher basicity the slag shows less viscous behavior at the same temperature ${ }^{19-21}$. According to Monaghan and $\mathrm{Chen}^{1}$, in addition to the change in slag viscosity, the dissolution rate of spinel inclusions increases with increasing slag basicity. Kumar and Sankaranarayanan ${ }^{22}$, Mills ${ }^{23,24}$ and Chuan et $\mathrm{al}^{25}$, apply the concept of optical basicity $(\Lambda)$ to the viscosity variation of liquid slags (molten silicates), concluding that the introduction of basic oxides $(\mathrm{CaO}, \mathrm{MgO})$ disrupt the lattice structure of silicates, resulting in decreased viscosity. 
Jönsson et al. ${ }^{15}$ verified that for slags of the $\mathrm{Al}_{2} \mathrm{O}_{3}$ $\mathrm{CaO}-\mathrm{MgO}-\mathrm{SiO}_{2}$ system containing the same contents of $10 \% \mathrm{MgO}$ and $10 \% \mathrm{SiO}_{2}$, from different $\% \mathrm{Al}_{2} \mathrm{O}_{3} / \% \mathrm{CaO}$ ratios, the increase in $\mathrm{CaO}$ content increases the viscosity, with this effect being more significant at temperatures below $1577^{\circ} \mathrm{C}$. Xu et al. ${ }^{26}$, using high-alumina and low $\mathrm{SiO}_{2}$ slag compositions, similar to those of ladle furnace and ESR slags, study the influence of the $\% \mathrm{CaO} / \% \mathrm{Al}_{2} \mathrm{O}_{3}$ mass ratio on the viscosity of the slag. The authors concluded that the viscosity decreases with the increase of the $\% \mathrm{CaO} / \% \mathrm{Al}_{2} \mathrm{O}_{3}$ mass ratio, however, at a determined ratio of $\% \mathrm{CaO} / \% \mathrm{Al}_{2} \mathrm{O}_{3}$, the viscosity starts to increase their value. This increase in the viscosity is associated with changes in phases and structures in the slags. Yoon et al. ${ }^{5}$ determined the optimized ratio $\left(\% \mathrm{CaO} / \% \mathrm{Al}_{2} \mathrm{O}_{3}\right)$ for bearing steels in the slag between 1.7 and 1.8 by the addition of $\mathrm{Al}_{2} \mathrm{O}_{3}$ and reduction of the $\mathrm{CaO}$, changing the slag to the composition of slags found in a region of low melting temperature. Dong et al. ${ }^{27}$ reports that a $\% \mathrm{CaO} / \% \mathrm{Al}_{2} \mathrm{O}_{3}>2$ ratio in slag increases total oxygen, decreasing the ability of slag to absorb oxide inclusions and facilitating high melt temperature inclusions in high ratios.

The objective of this study is to investigate the effects of composition variation of secondary refining slags (with or without $\mathrm{CaF}_{2}$ ) by analysing the effective viscosity and the control of non-metallic inclusions as a function of the $\mathrm{Al}_{2} \mathrm{O}_{3}$ content during the manufacturing process of DIN 38MnS6 steel. As specific objectives, data on steel and slag samples were collected in different stages of a steelmaking plant. In addition, characterization of the non-metallic inclusions in the steel samples and thermodynamic calculations to determine the effective viscosity, solid fraction, liquid fraction and $\mathrm{MgO}$ saturation point of these slags were performed in this study. Finally, the different sample types and results are compared and the interactions between slag and inclusions is discussed.

\section{Materials and Methods}

Industrial sampling method, chemical analysis, thermodynamic calculations, optical basicity calculation and inclusionary analysis will be presented in the following sections.

\subsection{Industrial sampling}

The DIN 38MnS6 steel, with chemical composition according to the standard ${ }^{28}$ shown in Table 1, follows these production stages: electric arc furnace (EAF), ladle furnace (LF), vacuum degassing (VD) and solidification in a continuous casting (CC) machine with three strands.
The deoxidation process applied includes aluminum (Al) addition during steel tapping and in the end of the vacuum degassing (VD). The inclusions treatment was provided by addition wire $\mathrm{CaSi}$. Steel and slag samples were collected immediately after the end of the vacuum degassing (VD). Futhermore, steel samples were also taken during the middle of the CC process, at the tundish (sample DT). The middle of the $\mathrm{CC}$ process is considered to be when approximately $50 \%$ of steel remains in the ladle, equivalent $30 \mathrm{t}$.

A total of nineteen heats were evaluated, and the steel samples (AP) were collected with commercial lollipop samplers from Heraeus Electro Nite. The slag samples (EP) were removed by insertion of a steel rod into the slag by the vacuum degassing operator. For the inclusionary analysis, the samples (DT) were collected with samplers without deoxidizer using the Samp-O-Line model, from Heraeus Electro Nite.

\subsection{Chemical analysis}

Except for the content of $[\mathrm{Mg}]$ in steel, all the other elements in the steel were analysed. The steel (AP and DT) and slag samples (EP) were subjected to X-ray fluorescence chemical analysis (FRX) using the equipment from Philips, PW2600 model.

\subsection{Thermodynamic calculations}

The thermodynamic calculations were performed with the objective of determining the following properties of the slag: solid fraction, liquid fraction, effective viscosity and $\mathrm{MgO}$ saturation point at a temperature of $1560^{\circ} \mathrm{C}$. The temperature of $1560^{\circ} \mathrm{C}$ was chosen based on the slag temperature in the continuous casting process. For the thermodynamic calculations, the FactSage 6.4 program was used. The databases applied were FactPS (for pure substances) and FToxid (for oxides and sulfur). As input data, the standard compositions of the A and B slags obtained in fluorescence analysis were applied. The $\mathrm{FeO}$ and $\mathrm{MnO}$ contents were very low (less than $2.5 \mathrm{wt} \%$ ) and therefore were disregarded. In the Equilib module, the slag parameters (solid fraction, liquid fraction and $\mathrm{MgO}$ saturation point) were determined for a range of $\mathrm{MgO}$ content from 0 to $35 \mathrm{wt} \%$, with $1 \mathrm{wt} \%$ increments. Through the Viscosity module, the viscosity values of the liquid slag were determined. Finally, the effective viscosity $\left(\eta_{\mathrm{e}}\right)$ was calculated using the RoscoeEinstein model (Equation 1), which takes into account the solid fraction present in the $\operatorname{slag}^{3,4,6,13,29}$

$$
\eta_{e}=\eta_{0}(1-a f)^{-n}
$$

Table 1. Chemical composition range of DIN $38 \mathrm{MnS} 6$ steel studied ( $\% \mathrm{wt}) .^{28}$

\begin{tabular}{lcccccccccc}
\hline Range & $\mathrm{C}$ & $\mathrm{Si}$ & $\mathrm{Mn}$ & $\mathrm{Al}$ & $\mathrm{P}$ & $\mathrm{S}$ & $\mathrm{Cr}$ & $\mathrm{Mo}$ & $\mathrm{Ni}$ & $\mathrm{Cu}$ \\
\hline Mín. & 0.36 & 0.20 & 1.30 & 0.010 & - & 0.045 & 0.10 & - & - & - \\
Máx. & 0.40 & 0.65 & 1.60 & 0.050 & 0.035 & 0.065 & 0.20 & 0.07 & 0.25 & 0.25 \\
\hline
\end{tabular}


where: $\eta_{0}=$ viscosity of liquid slag; $f=$ fraction of precipitated solid phases; $\mathrm{a}$ and $\mathrm{n}$ are empirical parameters, which are equal to 1.0 and 2.5 , respectively, for rigid spherical particles of different sizes and uniformly dispersed.

The FactSage software gives an adequate result for the viscosity calculations with fluoride slags $\mathrm{CaO}-\mathrm{SiO}_{2}-\mathrm{Al}_{2} \mathrm{O}_{3}-$ $\mathrm{MgO}-\mathrm{CaF}_{2}$. The FactSage model has been validated in previous studies $^{30-32}$, showing that the difference between calculated and experimental viscosity are estimated to be about $30 \%$. In fact, the FactSage method has the least amount of errors, when compared to others models.

\subsection{Optical basicity (1) calculation}

The concept of optical basicity has been reported ${ }^{23}$ as an alternative to providing measurements of the degree of depolymerization of liquid slags (molten silicates). Optical basicity is determined from the addition of other oxide species, which affect the slag structure and consequently its physical and chemical properties.

Values for viscosity of liquid slag were related to the optical basicity $(\Lambda)$, determined using Equation $2^{14,22}$

$$
\Lambda=\sum X i \cdot \Lambda i
$$

where: $\mathrm{X}_{\mathrm{i}}=\left(\mathrm{x}_{\mathrm{i}} \cdot \mathrm{O} / \Sigma \mathrm{x}_{\mathrm{i}} \cdot \mathrm{O}\right)$, molar fraction of equivalent cations (molar fraction of each component $\left(\mathrm{x}_{\mathrm{i}}\right)$ multiplied by the number of moles of oxygen $(\mathrm{O})$ present in the empirical formulas); $\left(\Lambda_{\mathrm{i}}\right)$, optical basicity of the components.

Table 2 shows the optical basicity values of the components used in the calculations. Mills $\mathrm{s}^{23}$ and Pretorius ${ }^{10}$ have reported a value of 0.43 and 0.67 for the $\mathrm{CaF}_{2}$ optical basicity. According to Mills and Shidhar ${ }^{24}$ this value is very low since the $\mathrm{CaF}_{2}$ is considered a network breaker, suggesting the value of 1.2. In this study, no significant differences were observed in the calculation of optical basicity between the values 0.67 and 1.2 adopted.

\subsection{Inclusionary analysis}

The steel samples (obtained with non-deoxidizing samplers) were previously sanded and polished, as recommended by ASTM E3 ${ }^{33}$, and analysed by ASPEX (Explorer model) equipped with an automated scanning electron microscope (SEM) coupled with an EDS probe, obtaining the chemical composition, shape and diameter of non-metallic inclusions. The pre-set adjustment parameters for automated quantitative analysis were based on ASTM 2142-08 ${ }^{29}$ : beam energy of $20.0 \mathrm{kV} ; 16 \sim 18 \mathrm{~mm}$ focus and particle diameter above 4 $\mu \mathrm{m}$. The mean surface area of the steel samples examined was $67 \pm 6 \mathrm{~mm}^{2}$ for A slags $77 \pm 8 \mathrm{~mm}^{2}$ for B slags. In the

Table 2. Optical basicity values for pure oxides and compounds $\mathrm{CaF}_{2}$ and $\mathrm{MgF}_{2} \cdot{ }^{10,23,24}$

\begin{tabular}{cccccc}
\hline $\mathrm{MgO}$ & $\mathrm{SiO}_{2}$ & $\mathrm{CaO}$ & $\mathrm{Al}_{2} \mathrm{O}_{3}$ & $\mathrm{CaF}_{2}$ & $\mathrm{MgF}_{2}$ \\
\hline 0.78 & 0.48 & 1 & 0.61 & $\begin{array}{c}0.67 \\
(1.2)\end{array}$ & 0.67 \\
\hline
\end{tabular}

ASPEX analysis, some filters were applied. Table 3 shows the classification rules used by ASPEX in the study of the inclusions of interest, which examine a range of compositions to represent each type of inclusion. In the Table 3, it is important to note that within the classification for oxides, the C-A-S (calcium aluminosilicates) type inclusions are also considered.

\section{Results and Discussion}

\subsection{Analysis of the chemical composition and properties of refining slags}

The results of the slag chemical compositions and main slag parameters calculated by FactSage 6.4 are shown in Table 4.

As shown in Table 4, two groups of slag are distinguished: A slags, denominated conventional samples, where the contents range from $7-13 \% \mathrm{Al}_{2} \mathrm{O}_{3}$ and $0-5 \% \mathrm{CaF}_{2}$ and $\mathrm{B}$ slags, denominated adjusted samples, which are of reduced contents and vary between 7-9 $\% \mathrm{Al}_{2} \mathrm{O}_{3}$ and $0-4 \% \mathrm{CaF}_{2}$.

In Table 4 are the results of the main slag parameters calculated by FactSage 6.4 at the temperature of $1560^{\circ} \mathrm{C}$, where the slag viscosity refers to the slag as sampled and where the solid fraction, liquid fraction and effective viscosity correspond to slag at the beginning of the $\mathrm{MgO}$ saturation point. The solid phases precipitated and predicted by FactSage 6.4 for all analysed samples, are composed of

Table 3. ASPEX classification rules adopted in this study in the inclusionary analysis.

\begin{tabular}{|c|c|}
\hline $\begin{array}{l}\text { Types of } \\
\text { inclusions }\end{array}$ & Classification rules \\
\hline $\begin{array}{l}\text { Al-Mg- } \\
\text { Ca }\end{array}$ & $\begin{array}{c}\mathrm{Al}>=30 \text { and } \mathrm{Ca}>=10 \text { and } \mathrm{Mg}>=5 \text { and } \\
(\mathrm{Al}+\mathrm{Ca}+\mathrm{Mg})>=70 \text { and }(100 * \mathrm{~S} /(\mathrm{Ca}+\mathrm{Al}+\mathrm{S}))<10\end{array}$ \\
\hline Al-Mg & $\begin{array}{c}\mathrm{Al}>=50 \text { and } \mathrm{Mg}>=2.5 \text { and }(\mathrm{Al}+\mathrm{Mg})>=70 \text { and } \\
(100 * \mathrm{~S} /(\mathrm{Ca}+\mathrm{Al}+\mathrm{S}))<10\end{array}$ \\
\hline Alumina & $\mathrm{Al}>=85$ \\
\hline $\begin{array}{l}\mathrm{Al} / \mathrm{Ca} \\
0.8-1.5\end{array}$ & $\begin{array}{c}(\mathrm{Al}+\mathrm{Mg}+\mathrm{Ca})>=5 \text { and }(100 * \mathrm{~S} /(\mathrm{Ca}+\mathrm{Al}+\mathrm{S}))<10 \\
\text { and } \mathrm{Ca}>20 \text { and } \mathrm{Al}>20 \text { and }(\mathrm{Ca}+\mathrm{Al})>=65 \text { and } \mathrm{Al} / \\
\mathrm{Ca}>=0.8 \text { and } \mathrm{Al} / \mathrm{Ca}<1.5\end{array}$ \\
\hline $\begin{array}{l}\mathrm{Al} / \mathrm{Ca} \\
1.5-3\end{array}$ & $\begin{array}{c}(\mathrm{Al}+\mathrm{Mg}+\mathrm{Ca})>=5 \text { and }(100 * \mathrm{~S} /(\mathrm{Ca}+\mathrm{Al}+\mathrm{S}))<10 \\
\text { and } \mathrm{Ca}>20 \text { and } \mathrm{Al}>20 \text { and }(\mathrm{Ca}+\mathrm{Al})>=65 \text { and } \mathrm{Al} / \\
\mathrm{Ca}>=1.5 \text { and } \mathrm{Al} / \mathrm{Ca}<3\end{array}$ \\
\hline $\begin{array}{l}\text { Al/Ca } \\
\text { ovr } 3\end{array}$ & $\begin{array}{c}(\mathrm{Al}+\mathrm{Mg}+\mathrm{Ca})>=5 \text { and }(100 * \mathrm{~S} /(\mathrm{Ca}+\mathrm{Al}+\mathrm{S}))<10 \\
\text { and } \mathrm{Ca}>20 \text { and } \mathrm{Al}>20 \text { and }(\mathrm{Ca}+\mathrm{Al})>=65 \text { and } \mathrm{Al} / \\
\mathrm{Ca}>=3\end{array}$ \\
\hline Oxides & $(\mathrm{Al}+\mathrm{Mg}+\mathrm{Ca})>=5$ and $(100 * \mathrm{~S} /(\mathrm{Ca}+\mathrm{Al}+\mathrm{S}))<10$ \\
\hline $\begin{array}{l}\text { CaS - } \\
\text { Oxide }\end{array}$ & $\begin{array}{c}(\mathrm{Al}+\mathrm{Mg})>=5 \text { and }(\mathrm{Ca}+\mathrm{S})>=5 \text { and } \mathrm{Ca}>\mathrm{S} \text { and } \\
\qquad \mathrm{Mn}<5 \text { and } \mathrm{Si}<5\end{array}$ \\
\hline $\begin{array}{l}\text { CaS- } \\
\text { MnS }\end{array}$ & $\begin{array}{c}\mathrm{S}>=10 \text { and } \mathrm{Ca}>=5 \text { and }(\mathrm{Al}+\mathrm{Mg})<5 \text { and } \mathrm{Si}<5 \text { and } \\
\mathrm{Mn}>=5\end{array}$ \\
\hline $\mathrm{CaS}$ & $\begin{array}{c}(\mathrm{Mn}+\mathrm{Al}+\mathrm{Mg})<5 \text { and } \mathrm{Ca}>=10 \text { and } \mathrm{S}>=10 \text { and } \\
\qquad \mathrm{Si}<5\end{array}$ \\
\hline
\end{tabular}




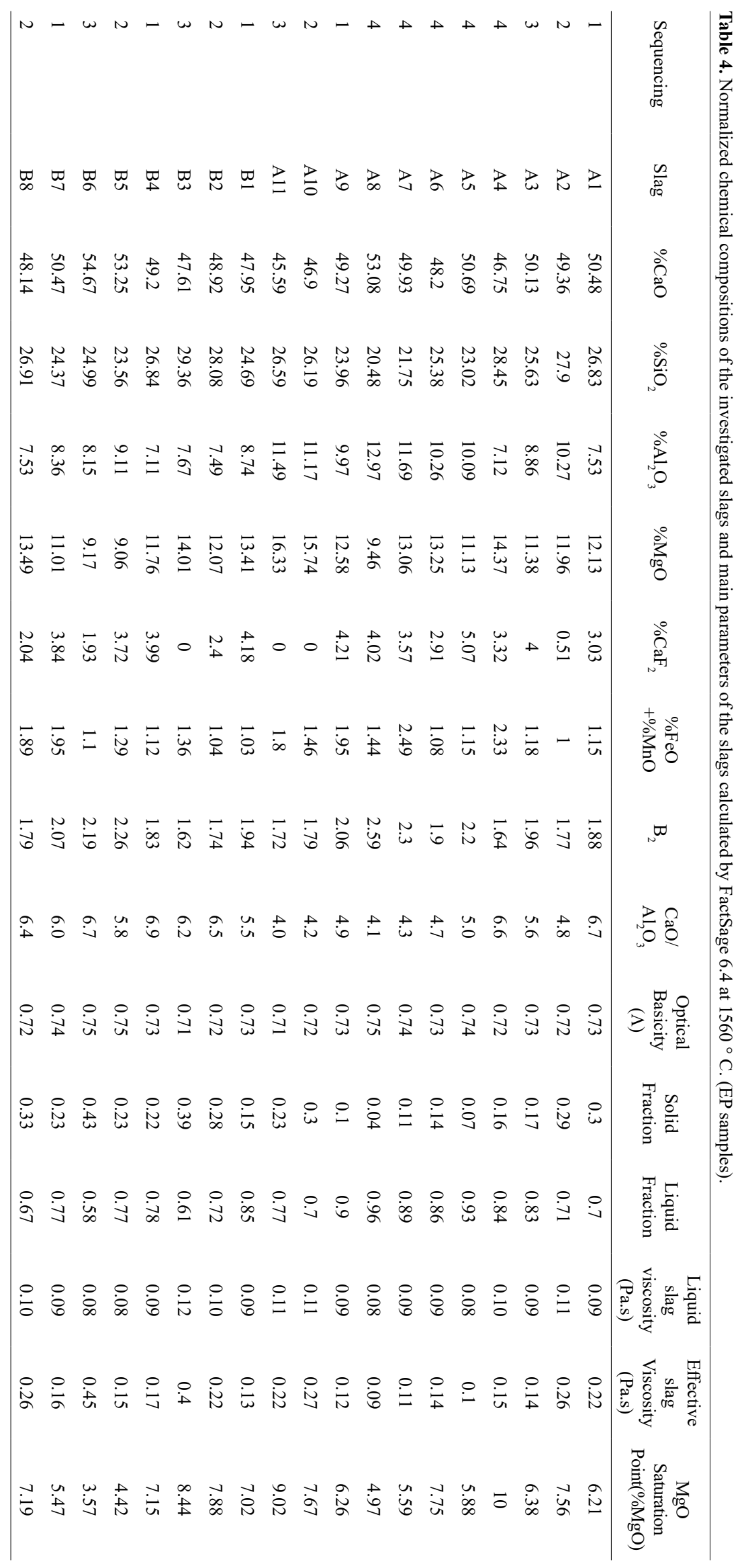


$\mathrm{C}_{2} \mathrm{~S}$ (dicalcium silicate) and $\mathrm{MgO}$ of similar trend with the results from Rocha et al. ${ }^{29}$ work.

Based on the results of Table 4, the samples were classified by groups according to the alumina content in the slag, in order to only investigate the influence caused by the different additions of fluorite $\left(\mathrm{CaF}_{2}\right)$ on the effective viscosity variation between the two slags series (A and $B$ ), shown graphically in Figure 1.

For an $\mathrm{Al}_{2} \mathrm{O}_{3}$ content of 7-7.5\%, except for the slag sample $\mathrm{B} 3$ without $\mathrm{CaF}_{2}$, comparison of samples $\mathrm{B} 8, \mathrm{~B} 2$, $\mathrm{A} 1, \mathrm{~B} 4$ and $\mathrm{A} 4$, increasing the additions of $\mathrm{CaF}_{2}$ between $2-4 \%$ produces a reduction in the effective viscosities of $0.26 \mathrm{~Pa} \cdot \mathrm{s}$ up to $0.15 \mathrm{~Pa} \cdot \mathrm{s}$, with increase of the liquid fractions from 0.67 to 0.84 . All samples compared in this category have low binary basicities in the order of 1.6-1.8. The slag sample $\mathrm{B} 8$ with addition of $2 \% \mathrm{CaF}_{2}$ present the value of $0.26 \mathrm{~Pa} \cdot \mathrm{s}$ of effective viscosity and a liquid fraction of 0.67 . The addition of $2.4-3 \% \mathrm{CaF}_{2}$ in the samples $\mathrm{A} 1$ and $\mathrm{B} 2$, kept the effective viscosity of the slags to a value of $0.22 \mathrm{~Pa} \cdot \mathrm{s}$ and the liquid fraction between 0.70 and 0.72 approximately constant. Compared to sample A1, a slight increase of $3.3 \%$ $\mathrm{CaF}_{2}$ is found in sample $\mathrm{A} 4$, which exhibits an effective viscosity fluctuation of $0.15 \mathrm{~Pa} \cdot \mathrm{s}$ and liquid fraction of 0.84 .

For an $\mathrm{Al}_{2} \mathrm{O}_{3}$ content of $8-8.5 \%$, the samples in the group (B6, B7, A3 and B1), present an effective viscosity change of $0.45 \mathrm{~Pa} \cdot \mathrm{s}$ to $0.13 \mathrm{~Pa} \cdot \mathrm{s}$ and a liquid fraction change from 0.58 to 0.85 . The samples present binary basicities on the order of 1.94-2.19.

A small tendency towards an increase in the range of effective viscosity and liquid fraction was found in the group (B6, B7, A3 and B1) samples in conjunction with an increase in the $\mathrm{CaF}_{2}$ content, as compared with the samples with an $\mathrm{Al}_{2} \mathrm{O}_{3}$ content between 7-7.5\%. Sample B6 with an addition of $2 \% \mathrm{CaF}_{2}$, presents an effective viscosity of $0.45 \mathrm{~Pa} \cdot \mathrm{s}$. For sample B7 with addition of a slightly lower amount of $3.84 \% \mathrm{CaF}_{2}$, it produces an effective viscosity of $0.16 \mathrm{~Pa} \cdot \mathrm{s}$. Samples A3 and B1 both with an addition of $4.0 \% \mathrm{CaF}_{2}$, reach similar effective viscosities, in the value of $0.14 \mathrm{~Pa} \cdot \mathrm{s}$ and $0.13 \mathrm{~Pa} \cdot \mathrm{s}$ respectively.

For an $\mathrm{Al}_{2} \mathrm{O}_{3}$ content of $9-10 \%$, in samples $\mathrm{A} 2\left(\mathrm{CaF}_{2}=0.51 \%\right)$, A6 $\left(\mathrm{CaF}_{2}=3 \%\right), \mathrm{A} 9\left(\mathrm{CaF}_{2}=4.21\right), \mathrm{B} 5\left(\mathrm{CaF}_{2} \sim 4 \%\right)$, A5 $\left(\mathrm{CaF}_{2}=5 \%\right)$, the effective viscosities corresponded to the

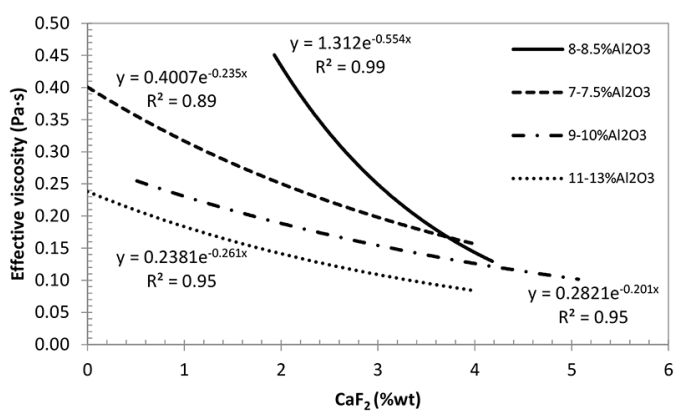

Figure 1. Influence of $\% \mathrm{CaF}_{2}$ additions on the effective viscosity of the slag in different alumina contents values of 0.26 to $0.10 \mathrm{~Pa} \cdot \mathrm{s}$, with liquid fractions of 0.71 to 0.93 , respectively. All samples compared in this category show low binary basicities on the order of 1.8-2.2.

For sample $A 5$, the same tendency as found in the groups above (B6, B7, A3 and B1, as well as B8, B2, A1, B4 and A4) was observed, being a reduction in the effective viscosity and an increase of the liquid fraction with the increase of $\mathrm{CaF}_{2}$ contents. However, in the case of A5, there was an even higher relation of this tendency compared to the groups mentioned above. Compared with sample A9, the sample B5, exhibits a fluctuation in effective viscosity reduction, possibly due to the insufficient $\mathrm{CaF}_{2}$ addition with the high $53 \% \mathrm{CaO}$ content present in this sample.

For an $\mathrm{Al}_{2} \mathrm{O}_{3}$ content of $11-13 \%$, the samples are subdivided into without addition of $\mathrm{CaF}_{2}(0 \%)$, where samples A10 and A11 show an effective viscosity of 0.27 and $0.22 \mathrm{~Pa} \cdot \mathrm{s}$, with a liquid fraction of 0.70 and 0.77 . And with addition of $4 \% \mathrm{CaF}_{2}$, where the samples $\mathrm{A} 7$ and $\mathrm{A} 8$, reached low effective viscosity in the value of $0.11 \mathrm{~Pa} \cdot \mathrm{s}$ and $0.10 \mathrm{~Pa} \cdot \mathrm{s}$ with high liquid fraction of 0.89 and 0.96 . All samples compared in this category show binary basicities in the order of 1.7-2.6. Again, slags with the addition of $\mathrm{CaF}_{2}$ demonstrate the lower effective viscosities and larger liquid fractions in relation to the slags without the addition of $\mathrm{CaF}_{2}$.

Moreover, additions of between $2-5 \% \mathrm{CaF}_{2}$ caused a reduction of the effective viscosities and an increase of the liquid fractions of the slag for the temperature of $1560^{\circ} \mathrm{C}$. However, for some of the slag compositions analysed, it has been observed that occasional viscosity fluctuations occur, possibly due to insufficient additions of $\mathrm{CaF}_{2}$. In addition, for the same $\mathrm{CaF}_{2}$ content, with higher $\mathrm{Al}_{2} \mathrm{O}_{3}$, the effective viscosity was smaller. These results are consistent with those of other researchers. $\mathrm{Wu}^{12}$ studied the influence of fluorite addition on high silica slags and its decrease in viscosity, concluding that the effect of $\mathrm{CaF}_{2}$ on viscosity strongly depends on the composition of the slag, and this effect is greater on slags with high content of $\mathrm{SiO}_{2}$ than with low $\mathrm{SiO}_{2}$ content. The presence of $\mathrm{CaF}_{2}$ should tend to depolymerize the silicate chains or molecules, leading to an expressive decrease in slag viscosity. For slags with high $\mathrm{SiO}_{2}$ content, $\mathrm{CaF}_{2}$ reduces the viscosity of the liquid phase and precipitation of the solid phases. For high basicity slags, $\mathrm{CaF}_{2}$ represses the precipitation of solid phases at low temperatures, leading to low viscosities compared to slags without $\mathrm{CaF}_{2}$ present. Shahbazian et al. ${ }^{16}$, report that in liquid slags containing $\mathrm{Al}_{2} \mathrm{O}_{3}$, aluminate complexes $\mathrm{Al}_{3} \mathrm{O}_{7}^{5-}, \mathrm{AlO}_{2}$, $\mathrm{AlO}_{3}{ }^{3-}$ can be formed. As the amount of $\mathrm{CaF}_{2}$ increases, aluminate anions can be depolymerized. The disintegration of the aluminate complexes into smaller units, resulting in a decrease in viscosity.

Regarding the viscosity values predicted by FactSage in this work, they are comparable to the values of viscosity measurements of $\mathrm{Wu}^{12}$ work, between $0,236-0,079 \mathrm{~Pa} \cdot \mathrm{s}$, for compositions of slag between $0-4 \% \mathrm{CaF}_{2}$ and $25 \% \mathrm{Al}_{2} \mathrm{O}_{3}$ in 
the temperature range of $1424-1632^{\circ} \mathrm{C}$. As with the viscosity results of Sui et $\mathrm{al}^{3}$, less than $1.0 \mathrm{~Pa} \cdot \mathrm{s}$ for slag compositions of $5 \% \mathrm{CaF}_{2}$ and $25 \% \mathrm{Al}_{2} \mathrm{O}_{3}$, in the temperature range of $1400-1500^{\circ} \mathrm{C}$ were confirmed.

The composition parameters, optical basicity $(\Lambda)$ and the $\% \mathrm{CaO} / \% \mathrm{Al}_{2} \mathrm{O}_{3}(\mathrm{C} / \mathrm{A})$ ratio of the slags modify effective viscosities and, consequently, their ability in the removal and composition of the inclusions, as can be seen in Figures 2 and 3. The $\mathrm{R}^{2}$ of the adjusted data regression for the two relations (Figures 2 and 3), can be considered adequate, given that the data come from the industrial environment, where there are many uncontrolled factors and therefore have been considered as noise.

Figure 2 shows the results of viscosities of liquid slag as a function of the optical basicity values $(\Lambda)$ for the samples of slags series A and B.

It is observed that the viscosities of liquid slag decrease linearly with an increase of optical basicity $(\Lambda)$. According to Tang et al. ${ }^{19}$ and Pengcheng et al. ${ }^{34}$, this behavior is associated with the presence of more free oxygen ions $\left(\mathrm{O}^{-2}\right)$ provided by the $\mathrm{CaO}$ dissociation when the basicity is increased, destroying the silicate network with a consequent decrease of the slag viscosity. This same trend of results in the influence of optical basicity on viscosity was also obtained by Kumar and Sankaranarayanan ${ }^{22}$.

Figure 3 shows the influence of the $\% \mathrm{CaO} / \% \mathrm{Al}_{2} \mathrm{O}_{3}$ ratio on the effective viscosity of the slags.

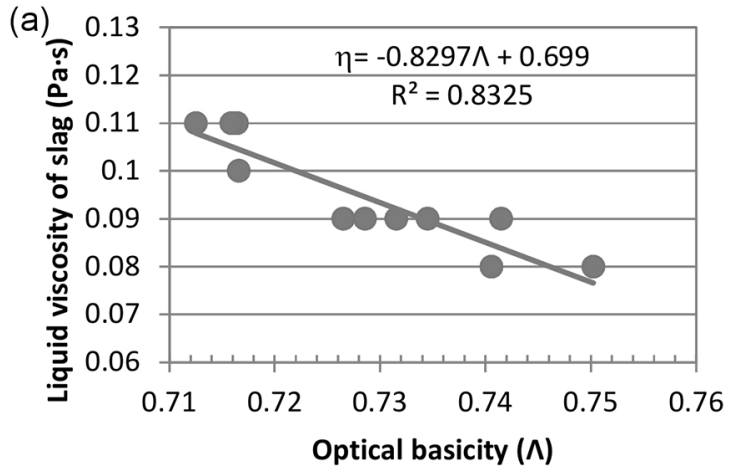

It is observed that the effective viscosity of the samples of series A vary little with the increase of the $\% \mathrm{CaO} / \% \mathrm{Al}_{2} \mathrm{O}_{3}$ ratio in relation to the samples of the series $\mathrm{B}$. This behaviour is attributed to series $\mathrm{A}$, because of the higher varying amounts of $\mathrm{Al}_{2} \mathrm{O}_{3}$ (together with the additions of $\mathrm{CaF}_{2}$ ) which maintains the fluidity of the slag with the increase in $\mathrm{CaO}$ content. Unlike the B series samples, where an increase in $\mathrm{CaO}$ additions with approximately constant $\mathrm{Al}_{2} \mathrm{O}_{3}$ contents results in a considerable increase in viscosity. Jönsson et al. ${ }^{15}$ also verified this tendency for slags of the $\mathrm{Al}_{2} \mathrm{O}_{3}-\mathrm{CaO}-$ $\mathrm{MgO}-\mathrm{SiO}_{2}$ system containing the same contents of $10 \%$ $\mathrm{MgO}$ and $10 \% \mathrm{SiO}_{2}$, from different $\% \mathrm{Al}_{2} \mathrm{O}_{3} / \% \mathrm{CaO}$ ratios. The increase in $\mathrm{CaO}$ content increases viscosity, with this $\mathrm{CaO}$ effect being more significant at temperatures below $1577^{\circ} \mathrm{C}$. According to Seok et al. ${ }^{13}$ and Song et al. ${ }^{35}$, the increase in viscosity is associated with the precipitation of solid particles.

A low viscosity is beneficial for mass transfer in the slag phase, so the choice of such slag composition in the production line should be essential ${ }^{15}$. Thus, for both series of slag samples (A and B) it is observed that, to obtain an effective viscosity below $0.20 \mathrm{~Pa} \cdot \mathrm{s}$, the optimum range of $\mathrm{C} / \mathrm{A}$ should comprise $4<\% \mathrm{CaO} / \% \mathrm{Al}_{2} \mathrm{O}_{3}<6.5$. This range is much larger than that found by Yoon et al. ${ }^{5}$ for bearing steels, where the ratio $\left(\% \mathrm{CaO} / \% \mathrm{Al}_{2} \mathrm{O}_{3}\right)$ optimized in the slag was controlled between 1.7 and 1.8 by the addition of $\mathrm{Al}_{2} \mathrm{O}_{3}$ and reduction of the $\mathrm{CaO}$, thus changing the composition

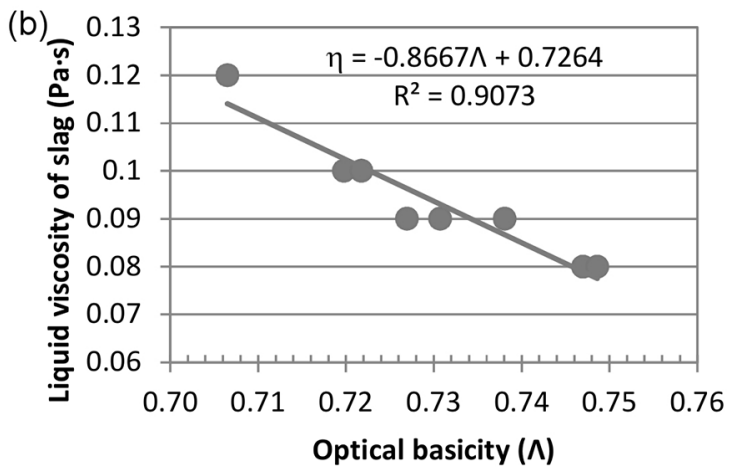

Figure 2. Viscosities of liquid slag versus optical basicity for (a) A slags and (b) B slags
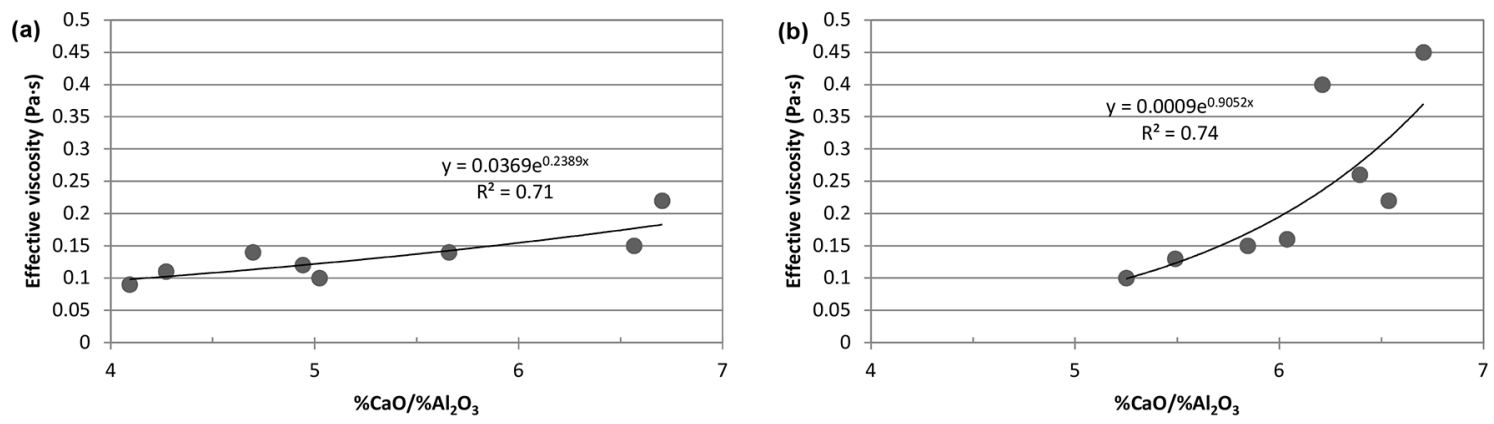

Figure 3 . Influence of the $\% \mathrm{CaO} / \% \mathrm{Al}_{2} \mathrm{O}_{3}$ ratio on the effective viscosity of the slags, being (a) A slags and (b) $\mathrm{B}$ slags 
of the slag to the region of low melting temperature and reducing total oxygen.

\subsection{Inclusionary analysis}

Figure 4 shows the typical distributions of the inclusion compositions for samples $\mathrm{A} 4, \mathrm{~A} 8, \mathrm{~B} 3$ and $\mathrm{B} 5$, shown on the ternary diagrams of the $\mathrm{CaO}-\mathrm{Al}_{2} \mathrm{O}_{3}-\mathrm{MgO}$ system.

As can be seen, the compositions of the inclusions for sample A4 are quite heterogeneous and are of a larger number than the inclusions in sample A8. This latter sample presented inclusions of alumina and spinel. In the other hand, for both samples B3 and B5 the inclusions are smaller in number. Sample B3 shows the concentrated inclusions of solid aluminate calcium formed and the inclusions are located near the binary axis $\mathrm{CaO}-\mathrm{Al}_{2} \mathrm{O}_{3}$ of the region of low melting point. In sample $\mathrm{B} 5$, less concentrated inclusions rich in $\mathrm{CaO}$ and $\mathrm{MgO}$ are observed.

Figure 5 shows the inclusion density results for the 2.55, 5-15 and $15 \mu \mathrm{m}$ diameter range, corresponding to the $\mathrm{A}$ and B steel samples series. These two groups are separated by the dashed line.

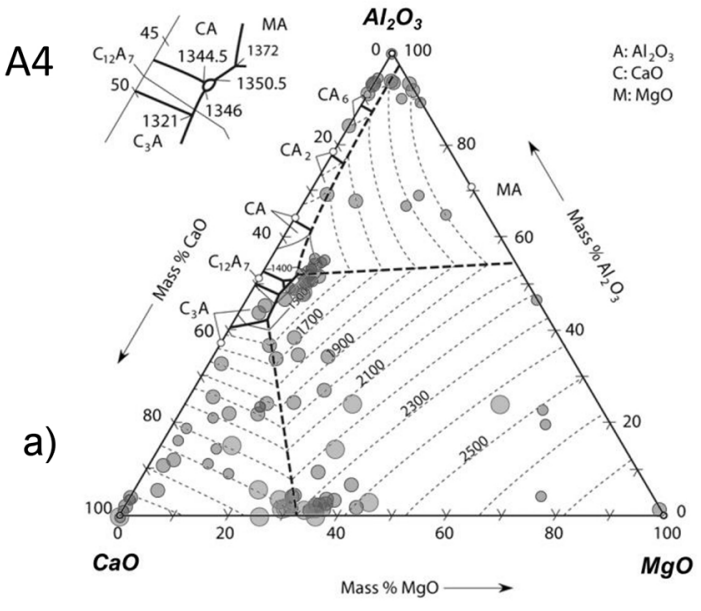

B3

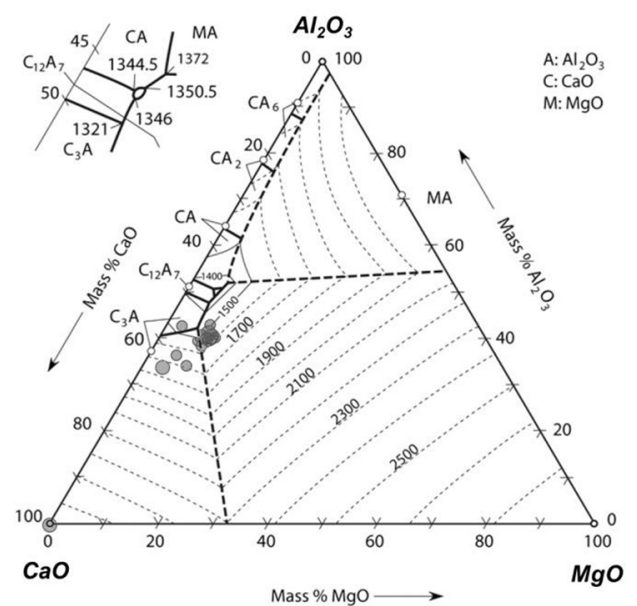

In general, most of the steel samples of the A series exhibit inclusion densities of $>0.10$ inclusions $/ \mathrm{mm}^{2}$, which is verified for the A1 and A9 samples (first of the sequence), the A2 and A10 samples (second of the sequence), A3 e A11 ( $3^{\text {rd }}$ sequence) and the A4, A5, A6, A7 samples (both of the $4^{\text {th }}$ sequence). In addition, for the B series, samples B1, B4 and B7 (first heat of the sequence), higher inclusion densities were found in relation to samples B2, B3, B5, B6, and B8, of similar densities of 0.10 inclusions $/ \mathrm{mm}^{2}$, similar to the A8 sample. On the other hand, only samples A4, A10, $\mathrm{B} 6$ and $\mathrm{B} 8$ show inclusions in the diameter range $\geq 15 \mu \mathrm{m}$. Capurro et al. ${ }^{36}$ report that inclusions larger than $15 \mu \mathrm{m}$ may correspond to inclusions of emulsification, refractory particles or re-oxidation inclusions.

The results of effective viscosities of the slags of both series $\mathrm{A}$ and $\mathrm{B}$, Table 4, with or without the presence of fluorite $\left(\mathrm{CaF}_{2}\right)$, and their influence on the steel cleanliness regarding the densities, size distribution and chemical composition of the inclusions, were also analysed as a part of this study. This analysis focused on steel samples with the lowest inclusion density.

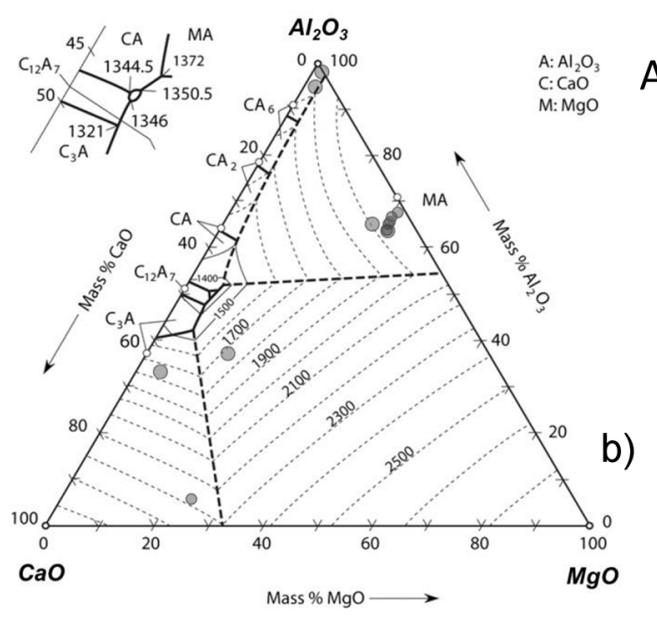

A8

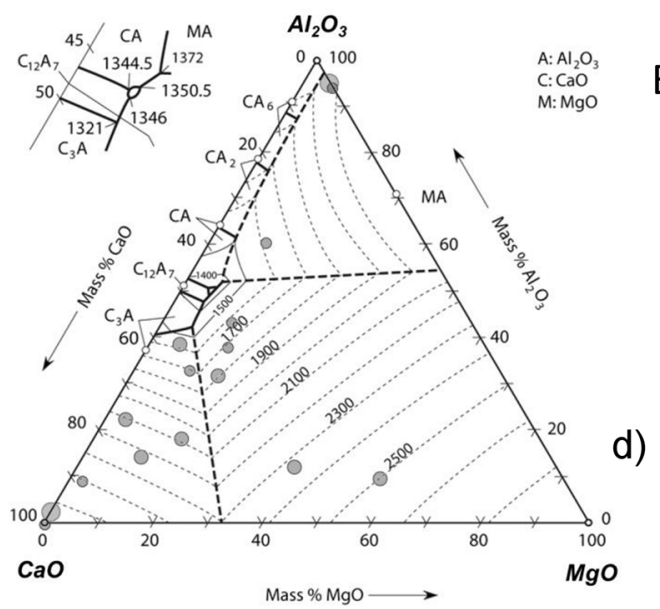

B5

Figure 4. Typical compositions of the oxidized inclusions of the samples: (a) A4, (b) A8 (c). B3, (d) B5. CaO- $\mathrm{Al}_{2} \mathrm{O}_{3}-\mathrm{MgO}$ system. Sample DT 
As shown in Figure 5, the gradual variation in the population of inclusions in the steel samples with 7-7.5 $\% \mathrm{Al}_{2} \mathrm{O}_{3}$ content, follows the order $\mathrm{A} 4>\mathrm{A} 1>\mathrm{B} 4>(\mathrm{B} 2=\mathrm{B} 3=\mathrm{B} 8)$.

The steels samples B2, B3 and B8, present the lowest inclusion densities with 0.10 inclusions $/ \mathrm{mm}^{2}$. The B 8 steel sample is the only sample of this group with inclusions in the diameter range $\geq 15 \mu \mathrm{m}$. Besides the viscosities and liquid fraction results, the inclusion density, size and composition distribution, give the slag samples $\mathrm{B} 2\left(\mathrm{CaF}_{2}=2.4 \%\right)$, and $\mathrm{B} 3$ $\left(\mathrm{CaF}_{2}=0 \%\right)$ exceptional conditions for the absorption of inclusions, compared to slag B8. The composition inclusions of sample A4 and B3 are shown in Figure 4.

The variation in the population of inclusions in the steel samples with 8-8.5 $\% \mathrm{Al}_{2} \mathrm{O}_{3}$ content follows the order $\mathrm{B} 1>\mathrm{A} 3>\mathrm{B} 7>\mathrm{B} 6$.

The steel sample B6, although it contained the lowest inclusion density, was the only one that presented inclusions in the diameter range $>15 \mu \mathrm{m}$. This behavior can be explained by the insufficient $\mathrm{CaF}_{2}$ content $\left(\mathrm{CaF}_{2}=1.93 \%\right)$ added to the $\mathrm{CaO}$ solubilization (equivalent to $55 \% \mathrm{CaO}$ ), which consequently kept a high effective viscosity of $0.45 \mathrm{~Pa} \cdot \mathrm{s}$ and a smaller liquid fraction of 0.58 . Due to the formation of solid compounds, the removal of inclusions in the diameter range $>15 \mu \mathrm{m}$ was impaired. The $\mathrm{CaF}_{2}$ content of this slag sample (B6) is the same as slag sample $\mathrm{B} 8\left(\mathrm{CaF}_{2}=2 \%\right)$.

In slag samples containing 9-10\% $\mathrm{Al}_{2} \mathrm{O}_{3}$, the gradual variation in the population of inclusions of steel samples follows the order A6 $>$ A5 $>$ A $9>$ A2 $>$ B5. The steel sample $\mathrm{B} 5$ presents the lowest inclusion density of 0.10 inclusions/ $\mathrm{mm}^{2}$ of the samples in the group. The best performance in inclusion removal among the slag sample group was observed in sample $\mathrm{B} 5$ and is related to higher $\mathrm{CaO}$ content (53\%). However, the distribution of inclusion composition of steel sample B5 is not concentrated. Slag samples in this group are far from the region of low melting point and close to $\mathrm{CaO}$ corner with high content of $\mathrm{MgO}$. The composition inclusions of sample B5 is shown in Figure 4.

In the group of slag samples containing $11-13 \% \mathrm{Al}_{2} \mathrm{O}_{3}$, there are no $\mathrm{B}$ steel samples for this classification and, the gradual variation in the population of inclusions in the steel samples follows the order A10 $>$ A7 $>$ A11 $>$ A8. Steel sample A8 presents the lowest inclusion density of 0.10 inclusions $/ \mathrm{mm}^{2}$. Sample A8, with $4 \% \mathrm{CaF}_{2}$ and containing the highest content of $\mathrm{Al}_{2} \mathrm{O}_{3}(\sim 13 \%)$ in the slag, is attributed with a very low effective viscosity of $0.10 \mathrm{~Pa} \cdot \mathrm{s}$ and a liquid fraction of 0.96 . This slag shows a greater efficiency in the removal of the inclusions due to the low level of density of inclusions obtained. Sui et al. ${ }^{3}$ indicate that additions of $\mathrm{CaF}_{2}$ and $\mathrm{Al}_{2} \mathrm{O}_{3}$ in the slag used in the refining unit in the plant effectively decrease the slag viscosity. Another characteristic of sample A8 is its higher content of $53 \% \mathrm{CaO}$ (greater binary basicity - 2,6) among the other slag samples in this category. In addition, although it has the smallest difference between the $\mathrm{MgO}$ content in the slag and the saturation start point, it is observed that sample A8, has the largest population of spinel. This can be attributed to a more fluid slag (with a higher liquid fraction) and, therefore, more reactive, contributing to the increase of the spinel inclusions in relation to other samples. See composition inclusions of sample A8 in Figure 4.

From the above, Rocha et $\mathrm{al}^{37}$ affirms, from experimental results on the inclusion density variation during vacuum degassing, that lower viscosity values are more effective in steel cleanliness. However, higher viscosity values can be harmful to the inclusion removal by slag and an increased

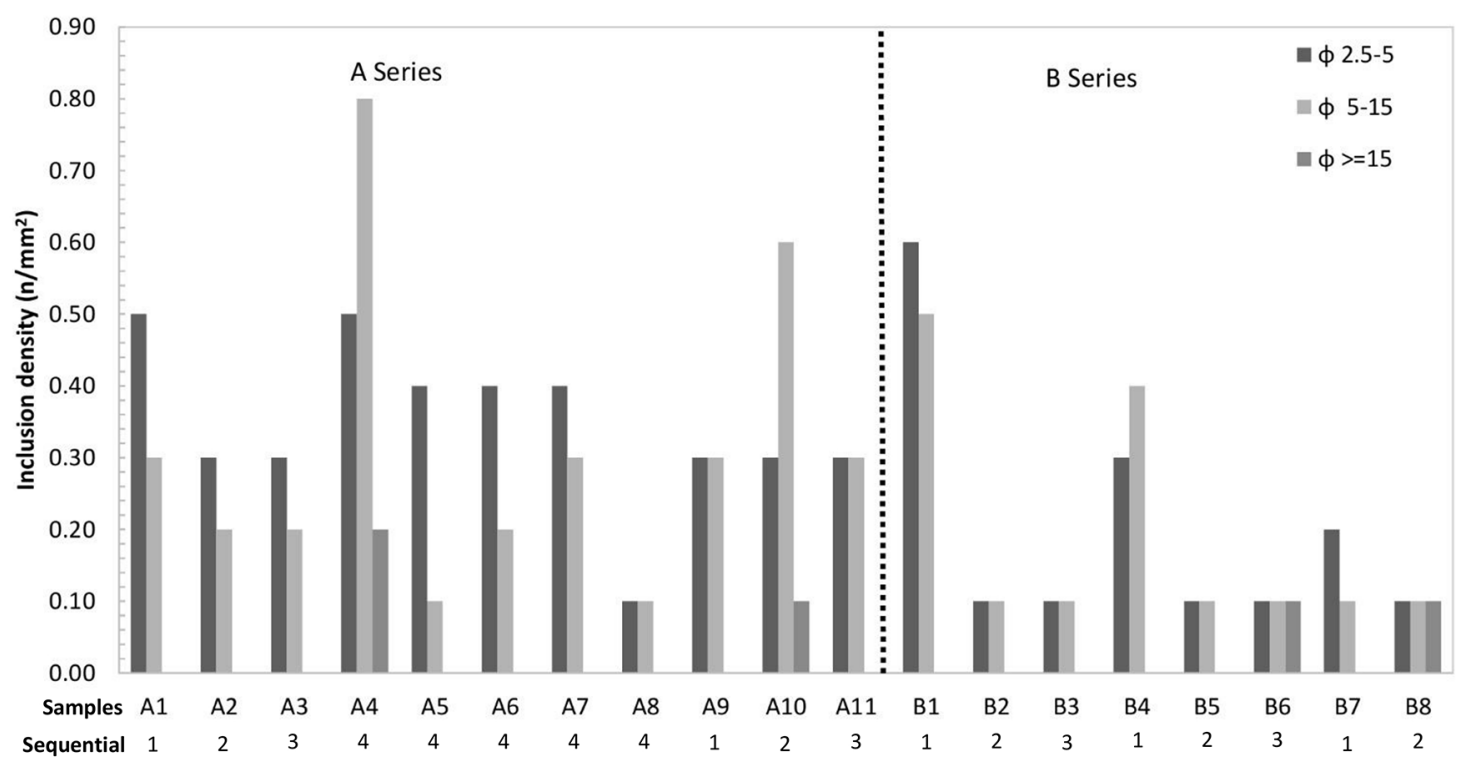

Figure 5. Comparison of density and size distribution of inclusions for A and B steel samples 
trend in the inclusion density after vacuum degassing, for all ranges of inclusions.

Another aspect observed in this work is related to the significant influence of the sequence of heats on the discussion of inclusion removal. The samples B1, B4 and B7, Figure 5, present the highest inclusion densities in relation to all other $B$ series steel samples, being verified that they correspond to the first heats of the sequence, which generally suggests that a re-oxidation of these heats occurred during the beginning of the continuous casting. According to Tang and Webler ${ }^{38}$, it is known from the literature that during the steel transfer operations from the ladle to the tundish, casting of the first heats in the sequence is critical, which can lead to reoxidation of the steel and consequently an increase in the inclusion density. With respect to the heats of the A series samples, the first heat of the sequence did not present the highest values for inclusion density. Great variation in the inclusion density was observed in another sequence $\left(2^{\text {nd }}, 3^{\text {rd }}\right.$ and $\left.4^{\text {th }}\right)$, however, in these sequences was also shown a hard re-oxidation of steel. The results found in series A did not clarify the effect of the heat sequence on inclusion removal.

When comparing the different types of inclusions found in the steel samples, Figure 6, it was observed that B slags had a better performance in relation to A slags. From the statistical results (frequency of inclusions) it was determined that in relation to the total inclusions, $\mathrm{Al}_{2} \mathrm{O}_{3}$ inclusions in slag A were $(5.1 \%)$ and slag $\mathrm{B}(3.8 \%)$; for inclusions of $\mathrm{MgO} \cdot \mathrm{Al}_{2} \mathrm{O}_{3}$ in slag $\mathrm{A}(12.3 \%)$ and slag $\mathrm{B}(1.5 \%) ; \mathrm{CaO} \cdot \mathrm{Al}_{2} \mathrm{O}_{3} \cdot \mathrm{MgO}$ slag $\mathrm{A}(23 \%)$ and slag $\mathrm{B}(16 \%) ; \mathrm{CaO} \cdot \mathrm{Al}_{2} \mathrm{O}_{3}$ slag $\mathrm{A}(7.3 \%)$ and slag $\mathrm{B}(2.7 \%)$, and $\mathrm{CaS}$ inclusions in slag $\mathrm{A}(2.4 \%)$ and slag $\mathrm{B}(0.8 \%)$. The inclusions of $\mathrm{CaO} \cdot \mathrm{Al}_{2} \mathrm{O}_{3} \cdot \mathrm{SiO}_{2}$ were the most predominant in both slags, accounting for slag $\mathrm{A}(50 \%)$ and high values in the slag B (75.4\%).

With respect to the $[\mathrm{Al}]$ and $[\mathrm{Ca}]$ contents in the steel, the $\mathrm{Al}$ content dissolved in the steel is 80 to $140 \mathrm{ppm}$ for slag A and 80 to $90 \mathrm{ppm}$ for slag B. According to Zhao et a ${ }^{39}$ of their experimental results, $\mathrm{Al}_{2} \mathrm{O}_{3}$ activity in slag $\mathrm{A}$ is higher than in slag $\mathrm{B}$, the $[\mathrm{Al}]$ content in liquid steel balanced with slag $\mathrm{A}$ is higher than slag $\mathrm{B}$. This fact is confirmed in the present work, where the increase of the $\mathrm{Al}_{2} \mathrm{O}_{3}$ content in the slag is closely related to the content of [Al]. The contents of [Ca] in steel is 6-11 ppm in slag $\mathrm{A}$, whereas it is 8-9 ppm for slag $\mathrm{B}$. The average $\% \mathrm{CaO} / \% \mathrm{Al}_{2} \mathrm{O}_{3}$ ratio is slightly higher for B slag (6.25) than for A slag (5.0), so the $\mathrm{CaO}$ supply for the transformation of the inclusions towards the liquid region is favored for slag $\mathrm{B}^{39,40-42}$. In general, it is concluded that $\mathrm{Al}_{2} \mathrm{O}_{3}$ inclusions are formed as a result of re-oxidation by air (the effect of the oxidation degree in slag is smaller) and the decrease in temperature during the final step of the steel manufacturing process ${ }^{9,27,43}$. On the other hand, the formation of inclusions of pure spinel $\left(\mathrm{MgO} \cdot \mathrm{Al}_{2} \mathrm{O}_{3}\right)$ is facilitated due to an increase in slag fluidity, which leads to increased $\mathrm{MgO}$ erosion of slag line refractories, as well as $\mathrm{MgO}$ saturation, which increase the dissolved magnesium in the liquid steel ${ }^{1,9,10,17,18,44-48}$. Secondary spinel formation by re-oxidation after modification with calcium should also be considered ${ }^{38,45,47,49,50}$. In addition to these inclusions, formation of inclusions of type $\mathrm{CA}$ and $\mathrm{CaS}$ exist in a smaller proportion than those of CAS.

Finally, the selection of a specific slag composition to improve the removal of the inclusions, providing adequate viscosity with the lowest number (density), size distribution and inclusion composition, was assigned to the samples A8, B2 and B3. These last two slags had very similar compositions, however, without addition of $\mathrm{CaF}_{2}$ in sample $\mathrm{B} 3$, which indicates a saving process. A possible explanation for this unexpected behavior of sample B3 may be related to other factors than the slag functions, such as stirring of the metal bath, since it is an industrial process and many uncontrolled factors are present, as already pointed out previously ${ }^{29}$. Future experiments in the laboratory will be carried out to better clarify the effects observed here regarding the cleaning of steel by slag.

\section{Conclusions}

Analysing industrial data involving steel cleanliness and refining slags is a difficult task due to the various noncontrollable factors. However, in this study some important correlations between chemical composition of slag and its ability to remove non-metallic inclusions were established. Through chemical analyses and thermodynamic computational calculations performed for DIN $38 \mathrm{MnS} 6$ steel, the following conclusions are presented:

- For the system based on $\mathrm{CaO}-\mathrm{SiO}_{2}-\mathrm{Al}_{2} \mathrm{O}_{3}-\mathrm{MgO}$, additions of $\mathrm{CaF}_{2}$ from $2 \%$ to $5 \%$ and $\mathrm{Al}_{2} \mathrm{O}_{3}$ from
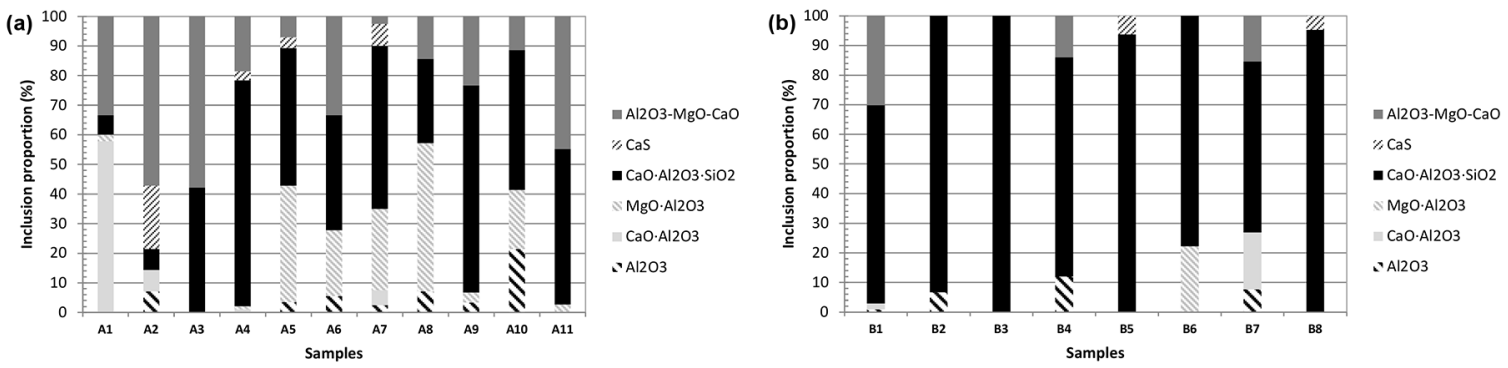

Figure 6. Types of inclusions for steel samples analysed with slag A and B 
$7-13 \%$, reduced the viscosity of the slag promoting effective viscosities from $0.45 \mathrm{~Pa} \cdot \mathrm{s}$ to $0.10 \mathrm{~Pa} \cdot \mathrm{s}$;

- $\quad$ For the ranges of slag composition studied, the values of effective viscosities decrease with increasing optical basicity;

- Increase in the $\% \mathrm{CaO} / \% \mathrm{Al}_{2} \mathrm{O}_{3}$ ratio in the samples of the A slags showed a lower viscosity variation, when compared to the samples of B slags;

- Heats of the first sequencing were more re-oxidized compared with other sequencing positions. Regarding the rest of sequencing, there was no clear distinction;

- Additions of up to $3 \% \mathrm{CaF}_{2}$, approximately, appear to be insufficient to significantly reduce the viscosity of the slag, making it difficult to remove inclusions of size $\geq 15 \mu \mathrm{m}$ in heats A4, A10, B6 e B8;

- The increase of $\mathrm{MgO}$ in the inclusions was correlated more clearly with the increase of the liquid fraction of the slag. Slag with a minimum of 0.83 of liquid fraction, presented greater amount of spinel inclusions;

- Increase of the liquid fraction of the slag promoted the conditions for the removal of inclusions, however it is important to take into account the negative effect of re-oxidation (generally noted in the first sequencing);

- $\quad$ Comparing A slags with B slags, B slags presented reduction of the alumina content and less re-oxidation events (except in the 1st sequencing), promoting the reduction of alumina and spinel inclusions, as well as the higher formation of CAS-type inclusions, which has an effect in the improvement of steel cleanliness;

- With the objective of an effective removal of the inclusions and reduction of steel-slag-refractory reactions, the optimal recommended viscosity range for the slags studied here was between 0.15-0.22 $\mathrm{Pa} \cdot \mathrm{s}$ and liquid fractions between $0.70-0.80$.

\section{Acknowledgements}

The authors are grateful to Gerdau Charqueadas, for their collaboration in obtaining the samples and heat data at the plant. Also to the CNPq, for the financial support through the Postdoctoral scholarship (Julio A. M. Pereira).

\section{References}

1. Monaghan BJ, Chen L. Effect of changing slag composition on spinel inclusion dissolution. Ironmaking \& Steelmaking. 2006;33(4):323-330.

2. Elfawakhry MK, Fathy A, Eissa M, Mattar T. Effect of steel composition and slag properties on NMI in clean steel production. MATEC Web of Conferences. 2016;39:02002.
3. Sui Y, Yue C, Peng B, Wang C, Guo M, Zhang M, et al. Optimization of Slag Chemistry Towards Inclusion Control for 28CrMo47 Drill Pipe Steel Based on Viscosity and Equilibration Studies. Steel Research International. 2016;87(6):752-760.

4. Reis BH, Bielefeldt WV, Vilela ACF. Efficiency of Inclusion Absorption by Slags during Secondary Refining of Steel. ISIJ International. 2014;54(7):1584-1591.

5. Yoon BH, Heo KH, Kim JS, Sohn HS. Improvement of steel cleanliness by controlling slag composition. Ironmaking \& Steelmaking. 2002;29(3):214-217.

6. Park JH, Kim DJ. Interfacial reaction between calcium silicate base flux and high manganese and aluminum alloyed steels. In: 8th International Conference on Clean Steel; 2012 May 14-16; Budapest, Hungary.

7. Valdez M, Shannon GS, Sridhar S. The Ability of Slags to Absorb Solid Oxide Inclusions. ISIJ International. 2006;46(3):450-457.

8. Ma WJ, Bao YP, Wang M, Zhao DW. Influence of slag composition on bearing steel cleanness. Ironmaking \& Steelmaking. 2014;41(1):2630 .

9. Valdez M, Prapakorn K, Sridhar S, Cramb AW. Dissolution of Inclusions in Steelmaking Slags. In: Proceedings of ISSTech 2003 Conference; 2003 Apr 27-30; Indianapolis, IN, USA. p. 789-798.

10. Pretorius E. The effect of Fluorspar in Steelmaking Slags. Baker Refractories; 1998. Available from: <http://etech.lwbref.com/ Downloads/Theory/The\%20Effect $\% 20$ of $\% 20$ Fluorspar $\% 20$ in $\% 20$ Steelmaking\%20Slags.pdf $>$. Access in: 15/5/2018.

11. Gran J, Wang Y, Sichen D. Experimental determination of the liquidus in the high basicity region in the $\mathrm{Al}_{2} \mathrm{O}_{3}(30$ mass \%) $\mathrm{CaO}-\mathrm{MgO}-\mathrm{SiO}_{2}$ system. Calphad. 2011;35(2):249-254.

12. Wu L, Gran J, Sichen D. The Effect of Calcium Fluoride on Slag Viscosity. Metallurgical and Materials Transactions $B$. 2011;42:928-931.

13. Seok SH, Jung SM, Lee YS, Min DJ. Viscosity of Highly Basic Slags. ISIJ International. 2007;47(8):1090-1096.

14. Asth HG. Desenvolvimento de escórias de refino secundário para o forno panela da V\&M do Brasil. [Dissertation]. Belo Horizonte: Escola de Engenharia da Universidade Federal de Minas Gerais; 2011

15. Jönsson PG, Jonsson L, Sichen D. Viscosities of LF Slags and Their Impact on Ladle Refining. ISIJ International. 1997;37(5):484-491

16. Shahbazian F, Sichen D, Seetharaman S. The Effect of Addition of $\mathrm{Al}_{2} \mathrm{O}_{3}$ on the Viscosity of $\mathrm{CaO}-" \mathrm{FeO}$ "- $\mathrm{SiO}_{2}-\mathrm{CaF}_{2}$ Slags. ISIJ International. 2002;42(2):155-162.

17. Bartosiaki BG, Pereira JAM, Bielefeldt WV, Vilela ACF. Estudo de inclusões não-metálicas em aços durante tratamento em desgaseificador a vácuo e início do lingotamento contínuo. In: $45^{\circ}$ Seminário de Aciaria da ABM; 2014 May 25-28; Porto Alegre, RS, Brazil.

18. Bartosiaki BG. Caracterização de inclusões não-metálicas de óxidos no aço SAE 52100.[Graduation Work]. Porto Alegre: Rio Grande do Sul Federal University; 2013.

19. Tang X, Zhang Z, Guo M, Zhang M, Wang X. Viscosities Behavior of $\mathrm{CaO}-\mathrm{SiO}_{2}-\mathrm{MgO}-\mathrm{Al}_{2} \mathrm{O}_{3}$ Slag With Low Mass Ratio of $\mathrm{CaO}$ to $\mathrm{SiO}_{2}$, and Wide Range of $\mathrm{A}_{2} \mathrm{O}_{3}$ Content. Journal of Iron and Steel Research, International. 2011;18(2):1-17. 
20. Chang KL, Su YH, Hwang WJ. Investigation of refining slag properties in production of SM570 welding structural steel. In: Proceedings of 9th International Conference on Clean Steel; 2015 Sep 8-10; Budapest, Hungary.

21. Gao Y, Wang S, Hong C, Ma X, Yang F. Effects of basicity and $\mathrm{MgO}$ content on the viscosity of the $\mathrm{SiO}_{2}-\mathrm{CaO}-\mathrm{MgO}-9 \mathrm{wt} \% \mathrm{Al}_{2} \mathrm{O}_{3}$ slag system. International Journal of Minerals, Metallurgy, and Materials. 2014;21(4):353-362.

22. Kumar M, Sankaranarayanan SR. Effect of optical basicity on the viscosity of oxide systems. Journal of Mining and Metallurgy. 2008;44(1)B:133-135.

23. Mills KC. The influence of Structure on the Physico-chemical Properties of Slags. ISIJ International. 1993;33(1):148-155.

24. Mills KC, Sridhar S. Viscosities of ironmaking and steelmaking slags. Ironmaking \& Steelmaking. 1999;26(4):262-268.

25. Hong C, Gao YM, Wang SB. Application of Optical Basicity for Estimation of Viscosity of $\mathrm{SiO}_{2}-\mathrm{CaO}-\mathrm{MgO}-\mathrm{Al}_{2} \mathrm{O}_{3}$ System. Advanced Materials Research. 2014;1033-1034:811-817.

26. Xu JF, Zeng T, Sheng MQ, Jie C, Wan K, Zhang JY. Viscosity of low silica $\mathrm{CaO}-5 \mathrm{MgO}-\mathrm{Al}_{2} \mathrm{O}_{3}-\mathrm{SiO}_{2}$ slags. Ironmaking \& Steelmaking. 2014;41(7):486-492.

27. Dong W, Ni H, Zhang H, Lü Z. Effect of slag composition on the cleanliness of $28 \mathrm{MnCr} 5$ gear steel in the refining processes. International Journal of Minerals, Metallurgy and Materials. 2016;23(3):269-275.

28. Deutsches Institut für Normung. DIN EN 10267: ferriticpearlitic steels for precipitation hardening from hot-working temperatures. Berlin: Deutsches Institut für Normung; 1998. $20 \mathrm{f}$.

29. Rocha VC, Pereira J, Yoshioka A, Bielefeldt W, Vilela A. Evaluation of Secondary Steelmaking Slags and Their Relation with Steel Cleanliness. Metallurgical and Materials Transactions B. 2017;48(3):1423-1432.

30. Liu Z, Pandelaers L, Jones PT, Blanpain B, Guo M. Effect of $\mathrm{Al}_{2} \mathrm{O}_{3}$ and $\mathrm{SiO}_{2}$ addition on the viscosity of $\mathrm{BOF}$ slag. Advances in Molten Slags, Fluxes, and Salts: Proceedings of the 10th International Conference on Molten Slags, Fluxes and Salts (MOLTEN16); 2016 May 22-25; Seattle, WA, USA. p. 439-445.

31. Rocha VC, Silva ML, Bielefeldt WV, Vilela ACF. Assessment of viscosity calculation for calcium-silicate based slags using computational thermodynamics. REM Int Eng J. 2018;71(2):243-252. DOI: http://dx.doi.org/10.1590/037044672017710029

32. Kim WY, Jung IH, Decterov S, Pelton AD. Modeling viscosity of molten slags and fluxes. In: Proceedings of $9^{\text {th }}$ International Conference on Clean Steel; 2015 Sep 8-10; Budapest, Hungary.

33. ASTM International. ASTM E 3-11 - Standard Guide for Preparation of Metallographic Specimens. West Conshohocken: ASTM International; 2011.

34. Li P, Ning X. Effects of $\mathrm{MgO} / \mathrm{Al}_{2} \mathrm{O}_{3}$ Ratio and Basicity on the Viscosities of $\mathrm{CaO}-\mathrm{MgO}-\mathrm{SiO}_{2}-\mathrm{Al}_{2} \mathrm{O}_{3}$ Slags: Experiments and Modeling. Metallurgical and Materials Transactions B. 2016;47(1):446-457.
35. Song M, Shu Q, Sichen D. Viscosities of the Quaternary $\mathrm{Al}_{2} \mathrm{O}_{3}-\mathrm{CaO}-\mathrm{MgO}-\mathrm{SiO}_{2}$ Slags. Steel Research Inernational. 2011;82(3):260-268.

36. Capurro $\mathrm{C}$, Cerrutti $\mathrm{G}, \mathrm{Cicutti} \mathrm{C}$. Influence of vacuum degassing on steel cleanliness. In: Proceedings of 9th International Conference on Clean Steel; 2015 Sep 8-10; Budapest, Hungary.

37. Rocha VC, Pereira JAM, Yoshioka A, Bielefeldt WV, Vilela ACF. Effective Viscosity of Slag and Kinetic Stirring Parameter Applied in Steel Cleanliness During Vacuum Degassing. Materials Research. 2017;20(6):1480-1491.

38. Tan J, Webler BA. Reoxidation of inclusions after aluminum deoxidation and calcium treatment. In: Proceedings of $9^{\text {th }}$ International Conference on Clean Steel; 2015 Sep 8-10; Budapest, Hungary.

39. Zhao S, He SP, Guo YT, Chen GJ, Lv JC. Effect on cleanliness of molten steel with different refining slag systems for low alloy ship plate. Ironmaking \& Steelmaking. 2016;43(10):790-798.

40. Yang G, Wang X. Inclusion Evolution after Calcium Addition in Low Carbon Al-Killed Steel with Ultra Low Sulfur Content. ISIJ International. 2015;55(1):126-133.

41. Deng Z, Zhu M. Evolution Mechanism of Non-metallic Inclusions in Al-Killed Alloyed Steel during Secondary Refining Process. ISIJ International. 2013;53(3):450-458.

42. Hu Y, Chen WQ, Han HB, Bai RJ. Influence of calcium treatment on cleanness and fatigue life of 60Si2MnA spring steel. Ironmaking \& Steelmaking. 2017;44(1):28-35.

43. Park JH, Todoroki $\mathrm{H}$. Control of $\mathrm{MgO} \cdot \mathrm{Al}_{2} \mathrm{O}_{3}$ Spinel Inclusions in Stainless Steels. ISIJ International. 2010;50(10):1333-1346.

44. Tang Y. Effect of Slag Composition on Inclusion Control in LF-VD Process for Ultra-Low Oxygen Alloyed Structural Steel. Procedia Earth and Planetary Science. 2011;2:89-97.

45. Capurro C, Cerrutti G, Cicutti C. Estudio de la generación y modificación de las inclusiones tipo espinelas durante las etapas de metalurgia secundaria y colada continua. In: Proceedings of 19th IAS Steel Conference; Nov 5-7; 2013. Rosario, SF, Argentina.

46. Okuyama G, Yamaguchi K, Takeuchi S, Sorimachi K. Effect of Slag Composition on the Kinetics of Formation of $\mathrm{Al}_{2} \mathrm{O}_{3}$ $\mathrm{MgO}$ Inclusions in Aluminum Killed Ferritic Stainless Steel. ISIJ International. 2000;40(2):121-128.

47. Verma N, Pistorius PC, Fruehan RJ, Potter MS, Oltmann HG, Pretorius EB. Calcium Modification of Spinel Inclusions in Aluminum Killed Steel: Reaction Steps. Metallurgical and Materials Transactions B. 2012;43(4):830-840.

48. Jiang M, Wang XH, Wang WJ. Study on refining slags targeting high cleanliness and lower melting temperature inclusions in Al killed steel. Ironmaking \& Steelmaking. 2012;39(1):20-25.

49. Pretorius EB, Oltmann HG, Cash T. The effective modification of spinel inclusions by Ca treatment in LCAK steel. In: Proceedings of AISTech 2009 - Iron and Steel Technology Conference; 2009 May 4-7; St. Louis, MO, USA.

50. Bao S, Wang X, Zhang L, Yang S, Peaslee KD. Improving Steel Cleanliness Through Slag Refining. Proceedings of AISTech 2008 - Iron and Steel Technology Conference; 2008 May 5-8; Pittsburgh, PA, USA. 